\title{
Potencijal za solidarnu ekonomiju u Splitu - kvalitativno istraživanje
}

\section{Jelena Puđak}

Institut društvenih znanosti Ivo Pilar, Zagreb, Hrvatska

e-mail: jelena.pudjak@pilar.hr

\section{Filip Majetić}

Institut društvenih znanosti Ivo Pilar, Zagreb, Hrvatska e-mail: filip.majetic@pilar.hr

\section{Dražen Šimleša}

Institut društvenih znanosti Ivo Pilar, Zagreb, Hrvatska e-mail:drazen.simlesa@pilar.hr

\begin{abstract}
SAŽETAK Temeljni cilj ovog rada istražiti je pokazuje li scena solidarnosti u Splitu neka od temeljnih obilježja koncepta solidarne ekonomije. Istraživanjem su obuhvaćeni ključni akteri scene solidarnosti u Splitu, tj. korišten je namjeran uzorak kombiniran s metodom snježne kugle, koji čini 21 nosilac upravljačkih pozicija iz devet organizacija različitih pravno-organizacijskih oblika (npr. udruge, zadruge, politička inicijative, tvrtke). Provedeni su polustrukturirani intervjui, a dobivena analitička građa obrađena je metodom tematske analize u kompjuterskom programu za obradu kvalitativnih podataka (Atlas ti.). Analizom se iskristaliziralo šest tema kroz koje ispitanici opisuju svoje djelovanje u području solidarnosti te stavove o vlastitom društvenom doprinosu i konceptu solidarne ekonomije. Teme obuhvaćaju: područje rada, definicije solidarne ekonomije, način rada organizacije, strukturu donošenja odluka, zagovaranje javnih politika i društveni doprinos. Utvrđeno je kako neki od nezaobilaznih elemenata scene solidarnosti u Splitu odgovaraju nekim od temeljnih obilježja solidarne ekonomije te kako se ključni akteri u tom području teško identificiraju s konceptom solidarne ekonomije.
\end{abstract}

Ključne riječi: solidarna ekonomija, scena solidarnosti, Split. 


\section{Uvodne napomene}

Društvena ekonomija, nova ekonomija, alternativna ekonomija, humana ekonomija, solidarna ekonomija, dobra ekonomija, održiva ekonomija i zelena ekonomija predstavljaju samo neke od koncepata uglavnom razvijanih još od 80-ih godina prošlog stoljeća kao izraz oponiranja mjerama dominantnog ekonomskog sustava, tj. neoliberalnog kapitalizma. S ulaskom u globalnu recesiju krajem prvog desetljeća 21. stoljeća, s poteškoćama u funkcioniranju te povećanim nezadovoljstvom rezultatima neoliberalizma na površinu izlazi sve više njegovih urođenih i stečenih nedostataka i kontradiktornosti. Time je ponajprije u akademskoj zajednici i na sceni civilnog društva otvoren dodatan prostor aktualiziranju i promišljanju, ali i pokretanju novih, drugačijih, dodatnih ili (čak) zamjenskih ekonomija. Ovaj rad usmjeren je na proučavanje solidarne ekonomije, u društvenim znanostima Hrvatske rijetko spominjane i istraživački dosad neobrađene „drugačije” ekonomije ${ }^{1}$. U okviru rada donosimo rezultate kvalitativnog istraživanja kojim smo željeli detektirati postojanje osnovnih obilježja solidarne ekonomije kod nas, preciznije u gradu Splitu.

\section{Pluralizam koncepta i polit-ekonomske implikacije solidarne ekonomije}

U neoklasičnoj („ugovornoj“) ekonomiji, kao i u neoinstitutcionalnoj ekonomiji, slobodno tržište prvi je i glavni okvir ekonomskih aktivnosti (Nyssens, 2000., prema Lemaitre i Helmsing, 2011.). Ne-tržišna (ili redistributivna) ${ }^{2}$ ekonomija postoji, ali se smješta u sferu neuspjelih pokušaja tržišta da alocira dobra i servise. Ne-monetarna ekonomija tako ostaje skrivena (Lemaitre i Helmsing, 2011.). Međutim Polanyi (1944.) smatra kako svako društvo kombinira, kroz vrijeme te s obzirom na politički kontekst, različite ekonomske principe kruženja dobara i usluga; i tržište i reciprocitet. Standardna neoklasična teorija nudi nam minimalnu viziju poduzetništva, koje djeluje ili s ciljem maksimalizacije profita ili s ciljem efikasnih (tehničkih) rješenja, koja ostavljaju malo mjesta za logiku i vrijednosti koje nose projekti solidarne ekonomije, a koja uključuje višestruke ciljeve (Lemaitre i Helmsing, 2011.).

Kako tumače Lemaitre i Helmsing (2011.), Polanyi vidi ekonomiju kao institucionalizirani politički proces. Ako organizacija ovisi o svom okolišu, također je u mogućnosti generirati promjene u tom okolišu. Institucionalizacija organizacija solidarne ekonomije recipročan je proces u kojem, s jedne strane, te organizacije igraju ulogu u javnoj debati kako bi konstruirale kolektivnog aktera (prepoznatljivog u javnoj sferi) i kako bi sudjelovale u razvoju javnih politika. S druge strane, njihova specifična

1 Na ovom mjestu željeli bismo spomenuti rad „Grupe solidarne razmjene - početci ekonomije solidarnosti u Hrvatskoj" (Orlić, 2014.) koji predstavlja rijedak primjer bavljenja tom temom kod nas.

2 U suvremenim društvima centralni je autoritet za organizaciju redistribucije dobara demokratska država. Princip reciprociteta kruženja dobara i usluga pretpostavlja specifične društvene veze između individua ili grupa koje primajući dar istom mjerom vraćaju, kao rezultat kompleksne povezanosti altruizma i osobnog interesa (Laville and Nyssens, 2001.). Pritom je ekonomska skala zajednica, a reciprocitet je utjelovljen u društvenim vezama. 
pozicija u javnoj sferi i javnim politikama može utjecati povratno na razvoj praksi tih istih organizacija.

Suočavajući se s društvenom krizom i manjkom javnih politika koje bi omogućile rješavanje problema, organizacije civilnog društva vide potrebu razvoja konkretnih akcija, kratkoročnih i dugoročnih ekonomskih alternativa koje će poduprijeti akcije u političkoj sferi kako bi se transformirale nepravedne strukture ili zahtijevala uspostava socijalne politike (Lemaitre i Helmsing, 2011.).

Scenu solidarne ekonomije čine organizacije s namjerom trajnog obavljanja ekonomske djelatnosti, kojima ta djelatnost, proizvodnja dobara ili usluga i natjecanje na tržištu predstavlja središnju, primarnu aktivnost te primarni izvor prihoda (Singer, 2007.). Međutim, unatoč tržišnoj orijentaciji (i prisutnosti plaćenog rada), istraživači naglašavaju kako se organizacije solidarne ekonomije oslanjaju i na volonterski (dobrovoljni, neplaćeni) rad te na kratkoročna financiranja iz javnih sredstava, nepovratna sredstva iz drugih izvora financiranja (engl. grant) i „pseudo-tržišne sheme" (primjerice kroz financiranje trećeg sektora kojima se organizacijama društvene ekonomije olakšava ulazak ili opstanak na tržištu) (Moulaert i Ailenei, 2005.:2049). Njihov pravno-organizacijski oblik pojavljuje se u rasponu od udruga do dioničkih društava i u pravilu ne predstavlja bitnu odrednicu fenomena (Singer, 2007.). Organizacije mogu sudjelovati u svim gospodarskim granama te mogu biti jednostavne i složene; jednostavne su organizacije npr. udruge sastavljene jednog ili svega nekoliko članova, a složene npr. platforma ili „skupine neprofitnih organizacija, kompleksnih zadruga te mreža poduzeća" različitih pravnih oblika (Singer, 2007.:46). Organizacije solidarne ekonomije, kao i svi ostali natjecatelji na slobodnom tržištu, teže samoodrživosti i rastu prihoda nad rashodima. Međutim dok taj rast prihoda nad rashodima kod aktera „konvencionalne“ ekonomije predstavlja krajnji cilj poslovanja, u slučaju solidarne ekonomije predstavlja (samo) sredstvo za ostvarivanje socijalne i/ili ekološke misije kao krajnjeg cilja (npr. trajno zapošljavanje teško zapošljive populacije, zbrinjavanje beskućnika ili sustavno čišćenje podmorja).

Koncept solidarne ekonomije prvi je puta spominjan još 1937. godine u Španjolskoj, dok je početkom 1980-ih u praksi zabilježen u Francuskoj, Kolumbiji i Čileu (Miller, 2010.:2). Korijeni europske inačice koncepta razlikuju se od one prisutne u zemljama Latinske Amerike. Primjerice, europska inačica snažno je oslonjena na koncept društvene ekonomije, dok je npr. ona Kolumbijska izgrađena na idejama kolumbijskog zadružnog pokreta (Miller, 2010.:2). Solidarna ekonomija do sredine je 1990-ih postala tema vrijedna pozornosti nešto šireg kruga ljudi u dijelovima Europe (Španjolska, Francuska), Latinske Amerike (Argentina, Meksiko, Peru, Brazil, Kolumbija, Čile) i Kanade (pokrajina Quebec), a nadnacionalnu dimenziju stječe krajem 1990-ih stvaranjem Međunarodne skupine solidarne ekonomije (španj. Grupo Internacional de Economia Solidaria ili GES), koja je kasnije narasla u Interkontinentalnu mrežu za promociju socijalno solidarne ekonomije (španj. Red Intercontinental de Promoción de la Economía Social Solidaria ili RIPESS) (Milller, 2010.:2). U posljednjih desetak godina solidarna ekonomija niknula je i u drugim dijelovima svijeta, Africi, Sjedinjenim Američkim Državama i Aziji (Miller, 2010.:2). Premda postoje sličnosti i s konceptom nastalim u SAD-u, društvenim poduzetništvom, brojni autori upozo- 
ravaju na različit razvojni smjer društvene i solidarne ekonomije (Ridley-Duff i Bull, 2013.; Laville, 2013.; Defourny i Nyssens, 2014.; Borzaga i Galera, 2014.).

Unatoč brojnim kulturama i oblicima u kojima se pojavljuje te raznovrsnim pristupima konceptualizaciji solidarne ekonomije, u nastavku izlažemo pregled nekih njezinih istaknutijih obilježja koja istraživači smatraju nezaobilaznima na globalnoj razini analize.

Prema Milleru (2010.), Kawano (2010.; 2013.), Uttingu (2015.) i istraživačima RIPESS-a (2015.), nekoliko je važnijih vrijednosti na kojima počivaju akteri solidarne ekonomije. Zbog potreba ovog rada njih smo podijelili u nekoliko skupina, koje se u određenim dijelovima međusobno preklapaju.

a) Solidarnost i njoj srodne vrijednosti, kao što su uzajamnost i snaženje duha zajednice (umjesto individualizma). Koncept solidarnosti korijene pronalazi u Rimskom pravu, gdje je solidarna obveza označavala „neograničenu odgovornost svakog pojedinca unutar obitelji ili druge zajednice za plaćanje zajedničkih dugova" (Bayertz, 1999.:3). Danas je jamac vraćanja duga u određenim situacijama obavezan solidarno u cijelosti (lat. in solidum) podmiriti dug koji sam nije napravio, ali je jamčio njegovo vraćanje. Od kraja 18. stoljeća uzajamna briga ili međuodgovornost pojedinaca nadilazi okvire prava i postaje važniji društveni mehanizam (Bayertz, 1999.:3). Nešto kasnije postaje i jedan od temeljnih predmeta interesa klasične sociologije (Comte, Durkheim, Weber, Marx) (Bayertz, 1999.:3). Iz perspektive suvremene sociologije solidarnost možemo definirati kao „društveni odnos u [...] skupini ljudi gdje se normativno i u pravilu uspješno postavlja zahtjev da pojedinac svoje osobne interese pod određenim uvjetima podredi interesima drugih, a u isti mu se mah stavlja u izgled da će drugi pod određenim uvjetima svoje interese podrediti njegovim" (Pusić, 1974.:130). To je društveni odnos u kojem obje strane (pojedinac i zajednica) prepoznaju potrebu jedna prema drugoj i zajednički interes u (takvom) odgovornom ponašanju jedna prema drugoj.

b) Društvena (i ekonomska) pravednost. Poopćeno i pojednostavljeno govoreći, društvena je pravednost „situacija u kojoj su povlastice i opterećenja u društvu distribuirani u skladu s nekim (pravednim) principom ili setom principa; u kojoj procedure, norme i pravila koje upravljaju politikom i drugim donosiocima odluka čuvaju osnovna prava i slobode pojedinaca i skupina i u kojoj se ljudska bića (i ostale vrste) tretiraju s dignitetom i poštovanjem ne samo od strane vlasti već i od strane svih drugih relevantnih društvenih aktera, uključujući njihove sugrađane“ (Jost i Kay, 2010.:1122). To je sustav u kojem su dokinuti „nepotrebna patnja, diskriminacija, tiranija, maltretiranje, opresija, predrasude i eksploatacija" (Jost i Kay, 2010.:1122). Ekonomska pravednost situacija je koja se postiže organizacijom područja ekonomije na (pravednim) principima, kao što su progresivno oporezivanje, uređeno tržište (bez monopolista i povlaštenih aktera), sankcionirani gospodarski kriminal ili etično poslovanje u smislu osiguravanja radnicima adekvatne kompenzacije za rad, mogućnosti poslovnog napredovanja i sindikalnog udruživanja te poštivanja potpisanih ugovornih obveza i redovitog plaćanja svih državnih i lokalnih nameta. 
c) Održivi gospodarski razvoj. Solidarna ekonomija zagovara ekonomiju koja u potpunosti razvija sve svoje potencijale na način da budućim generacijama ostavlja realnu mogućnost činjenja istog, ekonomiju čiji kreatori i egzekutori ideja razumiju i brinu o posljedicama koje njihove odluke donose društvu i okolišu (Utting, 2015.; RIPESS, 2015.). Konkretno, zagovara se ekonomija u kojoj su rast standarda društva te individualno i kolektivno blagostanje prioriteti, ekonomija u kojoj je maksimizirani profit samo sredstvo, ekonomija u kojoj je briga za ljude ispred profita i u kojoj ona (ekonomija) služi ljudima, a nikako obrnuto (Miller, 2010.; Utting, 2015.; RIPPES, 2015.). Solidarna ekonomija promovira aktere koji u svim sektorima (primarni, sekundarni i tercijarni) koriste ekološki osjetljive/ osviještene obrasce poslovanja (Miller, 2010.; Utting, 2015.; RIPPES, 2015.). Drugim riječima, ona inzistira na održivom gospodarskom razvoju i ne zadovoljava se gospodarskim rastom određenim rastom BDP-a (rastom industrijske proizvodnje, investicija itd.).

d) Demokratsko upravljanje. Solidarna ekonomija traži dobrovoljno i aktivno sudjelovanje svih članova/zaposlenika, izravno ili kroz izabrane predstavnike, u donošenju poslovnih odluka na svim razinama (Singer, 2007.). Također, podržano je „kolektivno vlasništvo“ članova/zaposlenika nad „sredstvima za proizvodnju” (npr. zadruge) (Singer, 2007.:46). Takav model upravljanja imovinom i procesima organizacija traži prihvaćanje inkluzivnosti i pluralizma, primjenu višedimenzionalnog pristupa izazovima u poslovanju kao izraz uvjerenja da „ne postoji samo jedan pravi put", visoku razinu socijalnog kapitala, podržavanje raznih akcija djelovanja odozdo (engl. bottom-up) te osnaživanje kooperacije umjesto kompeticije (unutar i između kompanija) (Miller, 2010.:6; RIPESS, 2015.).

e) Socijalna inovacija. Organizacije solidarne ekonomije teže savladavati izazove na putu do ispunjenja vlastite socijalne ili ekološke misije na inovativan način. Inovativnost se očituje u njihovoj izraženoj kreativnosti i poduzetnosti. Primjerice kroz stvaranje novih proizvoda i poslovnih modela ${ }^{3}$, unaprjeđivanje onih već provjerenih ${ }^{4}$ ili pokretanje globalnih inicijativa kroz akademski, poslovni ili sektor politikes.

f) Transformativni karakter. Solidarna ekonomija smještena je na sjecištu svih triju temeljnih stupova društva: privatnog (profitnog), javnog i nevladinog (neprofitnog) sektora (Kawano, 2013.). Njezina je ideja proširiti svoje postavke svim trima sektorima društva, tj. učiniti ih početnim postavkama globalnog socio-eko-

3 Primjerice mikrokreditiranjem po modelu banke Grameen iz Bangladeša omogućeno je financiranje onih koji zbog siromaštva nisu kreditno sposobni kod komercijalnih banaka te snaženje njihovog poduzetničkog duha i duha zajednice.

${ }^{4}$ Primjerice povećavanje efikasnosti dijelova proizvodnog procesa bolje promišljenim uključivanjem potencijala autista kao samo jednog primjera „teško uključive” skupine.

5 Primjerice promocija „,volonturizma” u Africi, kombinacije volonterizma i turizma kao sredstva za upoznavanje i senzibiliziranje šire javnosti s problemima potrebitih. 
nomskog sustava, ona nudi alternativu današnjem kapitalizmu (Kawano, 2010.; 2013.). Prema Kawano (2013.), „traži (pre)usmjeravanje države, mjera njezinih politika, trgovine, proizvodnje, distribucije, potrošnje, investicija, novaca i financija te vlasničkih struktura prema služenju blagostanju društva i okoliša”. Ili riječima Uttinga (2014.:149), solidarna ekonomija „naglašava važnost (stvaranja) alternative konvencionalnoj kompaniji usmjerenoj maksimalizaciji profita“ te konvencionalnim „obrascima proizvodnje i potrošnje, strategijama tržišnog rasta i odnosima moći“. Razlikovno obilježje i komparativna prednost solidarne ekonomije u odnosu na mnoge slične ekonomije/pokrete činjenica je da ona „cijeni i počiva na konkretnim praksama, a ne na stvaranju utopije na temelju teorije ili bez ikakvih temelja" (Kawano, 2013.).

Konkretno u Brazilu, primjerice, solidarna ekonomija predstavlja društveni pokret, i u očima aktera koji se tako identificiraju (FBES, 2006.) i u terminima opće prihvaćenih kriterija društvenog pokreta. Nadalje, u slučaju scene u Brazilu riječ je o međunarodnoj mreži aktera koji kroz suradnji i zajedničku mobilizaciju stvaraju projekte društvene promjene. Oni (akteri) imaju eksplicitnu namjeru provedbe univerzalne promjene u javnoj sferi i utjecaja na društveni život kroz otvaranje javnim (pravnim) tijelima (Platforma borbe). Okupljeni oko zajedničkog identiteta i zajedničkih vrijednosti, protagonisti tog pokreta protive se kapitalizmu te (militantno) brane „nov“ način proizvodnje, potrošnje i raspodjele bogatstva, alternativni model razvoja koji generira društvene koristi (Lemaitre i Helmsing, 2011.).

Ipak valja naglasiti kako dio sudionika nekih drugih scena solidarne ekonomije (npr. u SAD-u) sebe često niti vidi dijelom solidarne ekonomije niti akterima u procesu globalne socio-ekonomske transformacije (Kawano, 2010.:20). Za pretpostaviti je da je slična situacija prisutna i u nekim drugim zemljama. Prvi fenomen može biti objašnjiv činjenicom da su termin i koncept solidarne ekonomije relativno neprisutni u javnom diskursu, a drugi fenomen činjenicom da su akteri dio te scene iz isključivo pragmatičnih (društveno-ekonomskih) razloga, odnosno da ih politička promjena ili šira slika problema kojim se bave ne zanima (Kawano, 2010.:20).

U kontekstu transformativnog karaktera koncepta spomenimo i razliku između solidarne i društvene ekonomije budući da se ta dva koncepta u dijelu literature nerijetko poistovjećuju (Moulaert i Ailenei, 2005.; Kawano, 2013.). U drugom dijelu literature, ne zanemarujući pritom da ih na teorijskoj i praktičnoj razini vežu brojna zajednička obilježja, istraživači ističu jasne razlike. Primjerice Moulaert i Ailenei (2005.) solidarnu ekonomiju vide kao jednu od dimenzija društvene ekonomije. Prema istim autorima (2005.:2044), Laville (1992.) vidi solidarnu ekonomiju kao „novu generaciju društvene ekonomije s brojnim oblicima ekonomske aktivnosti”, a Lipietz (2001.) „smatra kako društvena ekonomija vidi solidarnu ekonomiju kao vlastito rasipno dijete, a solidarna ekonomija društvenu ekonomiju kao svog sklerotičnog roditelja”. Konačno, jedna je od razlika i želja za korjenitom promjenom. Za razliku od solidarne ekonomije koja se, već spomenuto, nalazi između nevladinog, javnog i privatnog sektora, društvena je ekonomija smještena unutar nevladinog (trećeg) sektora (Moulaert i Ailenei, 2005.; Kawano, 2013.). Društvena ekonomija time može biti shvaćena kao komplementarna neoliberalnom kapitalističkom sustavu ili njezin 
integralni dio s važnom ulogom u osvješćivanju i doprinosu rješavanju problema poput „siromaštva, nezaposlenosti ili društvene isključivosti“ (Kawano, 2013.). Tek „radikalno krilo društvene ekonomije konvergira s konceptom solidarne ekonomije“ u smislu da teži (potpuno) promijeniti danas dominantni sustav (Kawano, 2013.). S takvim tumačenjem slaže se i mreža RIPESS, koja koristi koncept „društvena i solidarna ekonomija" (engl. Social Solidarity Economy), a koji uključuje solidarnu ekonomiju i „radikalno krilo“ društvene ekonomije (Kawano, 2013.).

S obzirom na izložena obilježja, možemo zaključiti kako organizacije solidarne ekonomije imaju značajne potencijale u rješavanju brojnih društvenih i okolišnih pitanja; u „stvaranju sinergije između lokalnih vlasti, privatnih poduzeća, države, građana” i nevladinog sektora (Moualert i Ailenei, 2005.:2042) te kako scena u cjelini ima izražene potencijale za koaliranje s širokim spektrom „drugačijih“ ekonomija (npr. dobra ekonomija) i svjetonazorski sličnih društvenih pokreta, kao što su okolišni ili pokreti za osnaživanje marginalnih skupina (Kawano, 2013.).

Podaci koje smo dobili kroz istraživački rad na projektu iPRESENT pokazuju nam da je u deset godina koliko možemo pratiti razvoj društvene ekonomije broj aktera postao stabilan, da raste broj zaposlenih, a ukupni godišnji prihodi prelaze nezanemarivih 178 milijuna kuna (Šimleša i sur., 2015.). Za očekivati je i da će razvojna strategija donesena u proljeće 2015. godine pomoći daljnji razvoj ovog područja, a isto vrijedi i za utjecaj europskih i svjetskih trendova koji sve više podupiru takve modele alternativnih ekonomija ${ }^{6}$. U Hrvatskoj, pojavom aktera koji promoviraju solidarnost i solidarnu ekonomiju, otvara se i prostor za znanstvenu valorizaciju tog fenomena. U nastavku rada prikazujemo rezultate kvalitativnog istraživanja stavova aktera o solidarnoj ekonomiji u gradu Splitu.

\section{Solidarna ekonomija u Splitu - kvalitativno istraživanje}

\subsection{Grad Split kao istraživački kontekst}

Rezultati istraživanja Lalića i Nazor provedenog 1998. godine kao najznačajnije probleme Splita prikazuju redom: „, nezaposlenost, kriminal, narkomaniju, propadanje privrede te siromaštvo umirovljenika“ (Lalić, 2002.:111-112). U istraživanju provedenom 2002. godine vodećih 20 lokalnih splitskih političara „društveno stanje toga grada ocjenjuju nepovoljnim i opterećenim brojnim problemima“, od kojih su najveći redom: „nezaposlenost, propadanje gradske privrede, prometna izolacija gra-

6 Primjerice EU podupire cijeli sektor kroz svoju Inicijativu za društveno poslovanje (Social Business Initiative), a u tom je smjeru do 2020. godine kroz razne programe i natječaje EU-a dostupno 85 milijuna eura, uglavnom kroz fondove (Europski socijalni fond - ESF i Europski fond za regionalni razvoj - EFRR). Također, Europska komisija namjerava kroz Europski program za zapošljavanje i društvene inovacije (European Programme for Employment and Social Innovation - EaSI) investirati u sektor 500 milijuna eura, što će još više osnažiti politiku zapošljavanja marginaliziranih skupina, odnosno cjelokupnu društvenu i solidarnu ekonomiju. 
da, socijalna ugroženost njegovih građana, urbanistička devastacija, nekvalitetna i nepoštena pretvorba vlasništva, neučinkovitost gradske administracije, apatija i besperspektivnost građana, narkomanija te političke podjele u gradu“ (Lalić, 2002.:106, 115).

Ipak, unatoč očito nagomilanim društvenim problemima drugog najmnogoljudnijeg grada u Hrvatskoj, empirijskim radovima u području društvenih znanosti pokriven je tek (manji) dio svih njih. Ta nekolicina radova usmjerena je na probleme kao što su socijalna i zdravstvena ugroženost (Lalić i Nazor, 1999.), zloporaba droga (Unković i Majdak, 2010.; Lalić, Nazor, Grubišić i Mardešić, 1997.), zbrinjavanje otpada (Stanić i Buzov, 2009.; Stanić, Buzov i Galov, 2009.) i zapošljivost (Relja i Bešker, 2011.).

Grad Split pokazao se kao istraživački zanimljiv slučaj kada je riječ o solidarnom radu na razini države. Split je po broju stanovnika drugi najveći grad Hrvatske, sa stopom nezaposlenosti od 18\% krajem 2014. godine (Barić, 2015.). Porastom broja nezaposlenih može se očekivati i porast socijalno ugroženih i marginaliziranih skupina, što pak stvara plodno tlo za razvoj scene solidarnosti na razini grada. Split je jedinstven grad u Hrvatskoj koji je kroz javnu nabavu sklapao ugovore s akterima društvene ekonomije, što je vidljivo u službenim gradskim aktima (Grad Split, Službeni glasnik br. 22/2014.). Za vrijeme mapiranja aktera za potrebe projekta iPRESENT najbitniji dionici na samom terenu koji su dio društvene ekonomije, kao i predstavnici nadležnih tijela kao što je Ministarstvo rada i mirovinski sustav, istaknuli su kako trenutno u Hrvatskoj ne postoji sličan primjer direktne i jasne javne nabave prema akterima društvene ekonomije te nam skrenuli pažnju na tu činjenice kao istraživački zanimljivu.

Također, postoji inicijativa za promociju Splita kao „grada solidarnosti“, te je uspostavljena Platforma solidarnosti koja okuplja 35 udruga u Splitu. Navedeno je navelo autore ovog rada da istraže scenu solidarnosti u Splitu.

Solidarna ekonomija u užem smislu nije nužno poznat koncept društvenim akterima i aktivistima. Sve donedavno takav koncept manifestirao se samo kroz aktivnosti grupa solidarne razmjene i konkretne aktivnosti pomoći potrebitima. Godine 2015. jedan od aktera koristi koncept solidarne ekonomije kao obilježje identiteta, što otvara priliku za znanstveno proučavanje vezanih procesa od njihovih početaka i utjecaja na lokalnu zajednicu.

\subsection{Cilj istraživanja $i$ istraživačko pitanje}

Vodeći se određenjima solidarne ekonomije koje smo iznijeli u teorijskom pregledu, željeli smo istražiti podudarnosti djelovanja aktera na sceni solidarnosti u gradu Splitu i solidarne ekonomije kako je definiraju istaknuti autori.

Iz definicija navedenih u ovom radu možemo ekstrahirati sljedeće dimenzije koje autori navode kao ključne odrednice solidarne ekonomije: a) odmicanje fokusa od maksimalizacije profita, b) alternativni obrasci proizvodnje i potrošnje, c) djelovanje 
s ciljem društvene promjene, d) promjena odnosa moći te e) sociokulturna integracija marginaliziranih skupina.

U skladu s navedenim cilj istraživanja ispitati je stavove ključnih aktera scene solidarnosti u Splitu o solidarnoj ekonomiji. Istraživačko pitanje kojim se pritom vodimo je: pokazuje li scena solidarnosti u Splitu neka temeljna obilježja solidarne ekonomije?

\subsection{Metodologija}

U uzorak su birani ispitanici iz organizacija koje se bave radom na području solidarnosti, a koji su unutar svojih organizacija nosioci upravljačkih pozicija i/ili voditelji tekućih projekata. Ispitanici su podjednako bili pripadnici civilnog, privatnog i javnog sektora. Dakle odlučili smo se za namjeran uzorak, kombiniran s metodom snježne kugle. Istraživanje je provedeno na uzorku od dvadeset i jedne osobe iz devet organizacija (udruge, zadruge, politička inicijativa, tvrtke). Ti ispitanici/organizacije predstavljaju ključne aktere na području solidarne ekonomije grada Splita te su svi članovi Platforme solidarnosti.

Na tom uzorku provedeni su polustrukturirani intervjui, koji su obuhvaćali sljedeće tematske cjeline: područje rada i solidarnosti organizacije, definicija i ključni elementi solidarne ekonomije, pravni okvir i suradnja, upravljanje i organizacijska struktura.

Audiozapisi intervjua transkribirani su te je dobivena analitička građa obrađena u kompjuterskom programu za obradu kvalitativnih podataka Atlas ti. metodom tematske analize. Tematska analiza omogućila nam je raščlanjivanje i razvijanje obrazaca, odnosno tema koje su sadržane u analitičkoj građi, a koje su nam bile važne za opis i objašnjenje istraživanog fenomena te koje su relevantne za istraživačko pitanje. Tematsku smo analizu provodili putem kodiranja u šest faza kako bi se uspostavili obrasci koji tvore kategorije za analizu. Prilikom obrade podataka koristili smo otvoreno kodiranje.

\subsection{Rezultati istraživanja}

Analizom dobivene građe iskristaliziralo se šest tema kroz koje ključni akteri opisuju svoje djelovanje na području solidarnosti te stavove o vlastitom društvenom doprinosu i konceptu solidarne ekonomije. Teme obuhvaćaju sljedeće: područje rada, definicija solidarne ekonomije, način rada organizacije, struktura donošenja odluka, zagovaranje javnih politika, društveni doprinos. Rezultate istraživanja prikazujemo kroz pojedine teme. 


\subsubsection{Područje rada}

Slika 1.

Tema „područje rada“ i pripadajući kodovi

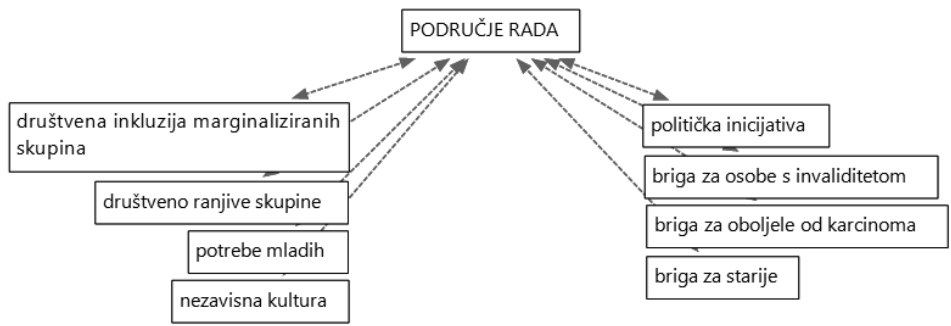

Područje djelovanja splitskih organizacija obuhvaća širok spektar solidarnog: od brige za mlade, oboljele od raka ili uključivanja marginalizirani skupina do nezavisne kulture i brige za socijalno ranjive skupine. Njihovo područje djelovanja pokriva socijalni i ekonomski aspekt održivosti, međutim gotovo ni jedna organizacija iz našeg uzorka ne obraća pažnju na ekološki aspekt održivosti, odnosno ne bave se kvalitetom okoliša bilo na lokalnom bilo na širem nivou.

Većina djelovanja i akcija ipak se odnosi na uključivanje marginaliziranih skupina i brigu za ranjive skupine građana. Rad s marginaliziranim skupina pritom se ne odnosi samo na zadovoljavanje potreba za hranom i/ili prenoćištem, već uključuje njihovu resocijalizaciju u društvo, i u formalno-pravnom i socio-kulturnom smislu, što ilustriraju sljedeći citati:

„Kontakti sa institucijama, posredovanje u ostvarivanju prava na socijalmu pomoc, osobnih dokumenata... oni kad dođu kod nas vrlo malo informacija imaju kome se i gdje obratiti tako da im mi pomažemo da ostvare svoja prava."

„Prenoćište koje ima svoju lepezu usluga, to je smještaj, odnosno privremeni boravak, osiguravamo mogućnost prehrane, osiguravamo zadovoljavanje osobne bigijene [...] Odnedavno nudimo i poludnevni boravak, tu im pružamo aktivnosti slobodnog vremena [...]."

Već tu možemo vidjeti približavanje djelovanja splitskih organizacija modelu solidarne ekonomije kako je definira Singer (2007.), stavljajući naglasak na osnaživanje i društvenu integraciju marginaliziranih skupina.

Također je uspostavljen sustav pomoći za građane koji žive ispod granice siromaštva, iako nisu beskućnici. Tu se radi o socijalnoj samoposluzi koja ugroženim skupinama omogućava da zadovolje dio egzistencijalnih potreba koristeći model dodjele bodova koji zamjenjuju novac.

„Socijalna samoposluga u Splitu nije za beskućnike, nego za one koji žive na rubu egzistencije. Bodove dobivaju s obzirom na broj članova kućanstva, 20 
bodova je procijenjena vrijednost od 20 kuna, znači samac dobije 20 bodova, bračni par 25, bračni par s jednim djetetom 30 i tako dalje, sve do 50. "

Kroz tu temu opisuju se primarni ciljevi i rad organizacija kroz rješavanje konkretnih problema u gradu, koje se odvija putem (samo)organizacije građana, dakle odozdo, bez inicijative lokalnih vlasti ili, u nekim slučajevima, financijske pomoći formalnih institucija.

\subsubsection{Definicija solidarne ekonomije}

Smatrali smo važnim ispitanike pitati kako bi vlastitim riječima definirali solidarnu ekonomiju te kako vide djelatnost vlastite organizacije s obzirom na koncept solidarne ekonomije. Pitanje smo im postavili bez da smo ih prethodno suočili s ikakvim određenjima ili definicijama, želeći otkriti kako bi je ključni akteri potencijalne solidarne ekonomije u Splitu definirali (što ona znači za njih u konkretnom društvenom kontekstu grada) te percipiraju li sami sebe kao dio jedne takve scene ili ne.

Slika 2.

Tema „definicija solidarne ekonomije“ i pripadajući kodovi

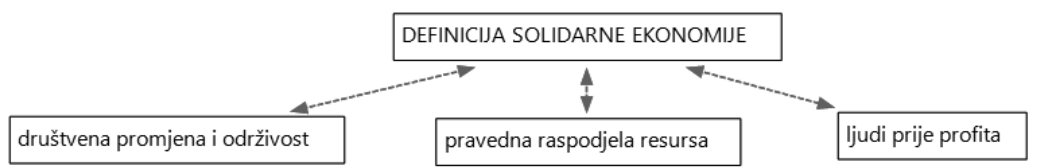

Zajedničko određenje solidarne ekonomije koje se pojavljuje u svim intervjuima odnosi se na naglašavanje koncepta društvene promjene (posebice iz klasne perspektive), zatim dijeljenja i održivosti.

„Za mene bi to treb'o bit nekakav novi model ekonomskog sustava koji se
ne bazira na podjeli između bogatih i siromašnih, koja za mene postaje sve
veća i mislim da je to neka 'bottom up' inicijativa koja kreće ono odozdo i
ljudi bi je trebali pokrenut."

„Solidarna ekonomija, ekonomija ne prvenstveno radi profita pojedinca ili firme. Pojam nekakve društveno korisne ekonomije, dakle nije jedini motiv isključivo profit, naravno da moraš pokrivat sebe $i$ svoje troškove $i$ zaradit nešto, ali vraćaš veliki dio u zajednicu. Dugoročno razmišljanje na dobrobit cijelog društva."

Iz tih citata možemo vidjeti kako sami ispitanici naglašavaju neke od ključnih momenata koncepta solidarne ekonomije koje možemo naći i u definicijama. Dakle dovodi se u pitanje ekonomski sustav u kojemu se kao cilj nameće maksimalizacija profita; također se dovode u pitanje odnosi moći i hijerarhijska struktura konvencionalnih poduzeća (vidi prvi citat). Kroz intervjue s ispitanicima javlja se novi moment kojim akteri definiraju solidarnu ekonomiju, a to je zastupanje javnog interesa, bilo da se 
radi o društvu u cjelini bilo lokalnoj zajednici. Iako točno pogađaju bitna obilježja koncepta solidarne ekonomije, većina aktera ipak se ne identificira s tim konceptom.

To ipak čini više pravilo nego iznimku. Naime, kao što je ranije spomenuto, Kawano (2010.:20) zaključuje kako većina aktera scene solidarne ekonomije u SAD-u sebe ne percipira kao takve, a razloge nalazi u činjenici da termin i teorijski koncept još uvijek nisu u široj javnosti prepoznati te da je sama konceptualizacija relativno slabo razvijena. To čini očitom potrebu za podizanjem svijesti i edukacijom o alternativnim ekonomskim modelima. Ipak, bez obzira na to nazivaju li sebe akteri solidarne ekonomije tako ili ne, i dalje smatramo korisnim identificirati elemente društvenog i ekonomskog djelovanja koji odgovaraju načelima solidarne ekonomije.

Ono što Kawano (2010.) smatra većim izazovom odsustvo je pokušaja šire ekonomske transformacije. Dakle neki od aktera primarno se bave rješavanjem praktičnih problema, te su manje involvirani u javno-političkoj sferi, što se naizgled ne uklapa u aspekt društvene promjene koju zagovara solidarna ekonomija. U slučaju našeg istraživanja, iako su ključni akteri s kojima smo razgovarali primarno zauzeti rješavanjem konkretnih problema u zajednici, ipak ih je većina svjesna potrebe za promjenom ekonomskog sistema, što su jasno u intervjuima i artikulirali. To se očituje u načinu na koji su sami definirali koncept solidarne ekonomije, ali i u načinu na koji organiziraju svoje aktivnosti te načinu na koji vide vlastiti doprinos zajednici. Osim toga, kako je prikazano u opisu prve teme, dio je aktera neposredno politički aktivan, dok dio nastoji utjecati na formiranje javnih politika putem civilnog djelovanja (više u temama „Zagovaranje javnih politika“ i „društveni doprinos“).

\subsubsection{Način rada organizacije}

Način na koji određena organizacija funkcionira prema unutra i prema van pokazuje nam koliko se ona zapravo razlikuje od konvencionalnog poduzeća te na koji način praktično dovodi u pitanje postojeće modele upravljanja, što nas je posebice zanimalo u slučaju kada organizacija nudi svoje proizvode i usluge na tržištu. Tema „način rada organizacije“ objedinjava šest kodova kojima smo označili razlikovna obilježja ključnih aktera scene solidarnosti grada Splita. Razlikovna su obilježja načina rada organizacija: modus društvenog djelovanja, neformalna organizacija rada, politička aktivnost, distinktivni modeli zapošljavanja i odvraćanje fokusa od maksimalizacije profita.

Slika 3.

Tema „način rada organizacije“ i pripadajući kodovi

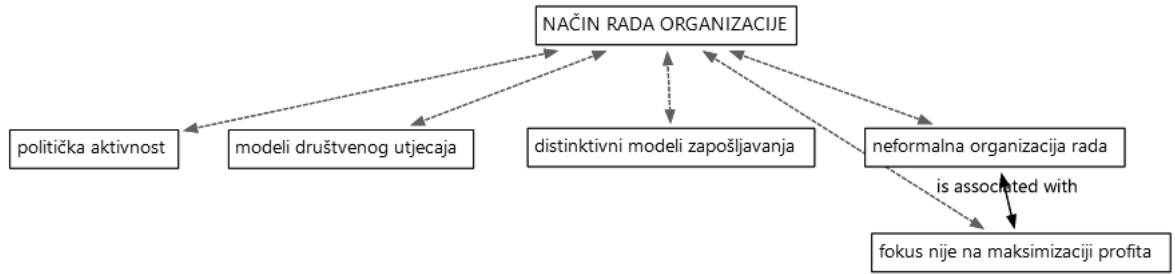


Ključni akteri često organiziraju svoje aktivnosti na neformalan način, koristeći društvene mreže, bez financijskih uloga i/ili potpore formalnih institucija. To ih zasigurno razlikuje od konvencionalnih poduzeća ili modusa rada u konvencionalnoj ekonomiji, te možemo reći i da dovodi u pitanje konvencionalne obrasce proizvodnje i (plaćenog) rada općenito.

„Nama je maksimalno pomogao fejs. Mi imamo naša dva rokovnika, imamo fejs grupu i fejs stranicu i to je to. I naša dva mobitela i evo... tri i po godine... "

„Prije je bilo drugačije, ovo je bilo mjesto gdje su mladi dolazili i gdje je neko radeći s njima dobivao plaću, mi smo ovo izokrenili u startu, mi smo svi smo bili volonteri, zajedno smo koordinirali, radili, razmjenjivali, davali najbolje od sebe i u tom smislu je zaživila ta filozofija da je ekonomski princip nevažan, ono, pisanje projekata pa imamo novac, pa nešto radimo - mi smo to radili sve $i$ bez toga."

Bilo da se radi o organizaciji prehrane za beskućnike bilo radu s mladima s poteškoćama u ponašanju, modeli proizvodnje (u obama slučajevima usluge) u potpunosti se razlikuju od modela u konvencionalnoj ekonomiji budući da se značajno oslanjaju na volonterski rad i donacije. Osim toga, potrošnja, odnosno korištenje usluge također je promijenjeno, posebice u radu s devijantnim mladima, koji su od pasivnih korisnika koji po nalogu komuniciraju sa službenom osobom postali aktivni korisnici koji se kroz „terapiju“ s vršnjacima i volonterski rad resocijaliziraju.

Također, nailazimo na distinktivni model zapošljavanja, odnosno na integraciju marginaliziranih skupina (beskućnika), pri čemu ekonomska integracija često vodi i u širu društvenu integraciju.

„Pa moja organizacija se bavi uključivanjem beskućnika na tržište rada. To je ja mislim najznačajnije. Oni su već uključeni, troje ib je uključeno kao zadrugari, a sada gledamo projekte kako da ib uključimo što više u poslovni proces."

Karakterističnom se pokazala tendencija šireg društvenog djelovanja organizacija, odnosno pokušaja utjecanja na društvene promjene u zajednici. Navedeno obuhvaća javno istupanje u obliku javnih predavanja, pojavljivanja u medijima ili uličnih akcija. Potonje pokazuje i pluralitet pojavnih oblika solidarne ekonomije o kojem govori i Dash (2014.). Naime Dash (2014.:7) solidarnu ekonomiju vidi kao krovni koncept raznolikih organizacijskih oblika, od lokalnih sustava razmjene do vremenskih banaka - a koje su sve važne društvene inovacije te predstavljaju alternativu konvencionalnoj ekonomiji.

Na taj način akteri solidarne ekonomije kroz ekonomske i ne-ekonomske inicijative te pomoću jakog socijalnog kapitala pokušavaju utjecati na porast kvalitete života i razvoj lokalne zajednice (Dash, 2014.:7). 


\subsubsection{Struktura donošenja odluka}

Slika 4.

Tema „struktura donošenja odluka“ i pripadajući kodovi

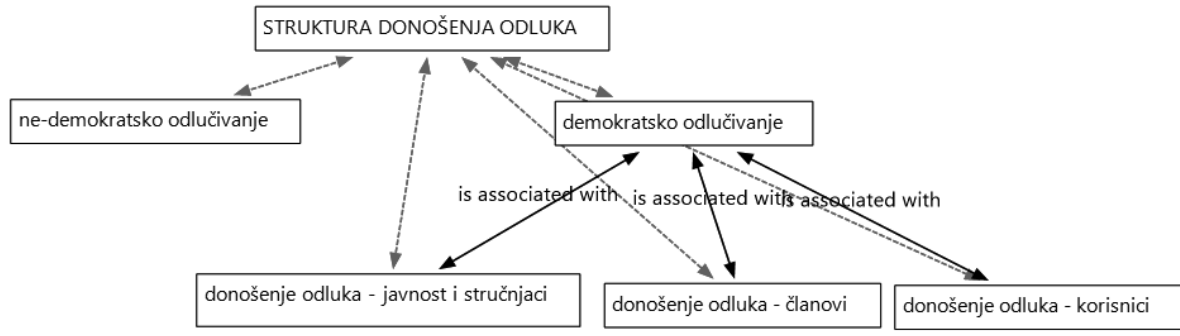

Struktura donošenja odluka u organizacijama koje smo istraživali općenito se može opisati kao demokratska ili nedemokratska (nedemokratskom možemo označiti samo jednu organizaciju).

Za aktere solidarne ekonomije, kao nosioce promjene, važno je da djeluju neovisno od države te da njeguju vrijednosti zajedništva (RIPESS, 2015.). U analiziranoj literaturi češce je naglašavano upravo samoupravljanje, demokratska struktura donošenja odluka te nedjeljivo zajedničko vlasništvo u organizaciji, a rjeđe su spominjani specifični oblici demokratskog upravljanja alternativni zastupničkoj demokraciji. U našem uzorku, u dijelu koji obuhvaća formalne organizacije, uglavnom ne nalazimo ništa što bi razlikovalo sudionike istraživanja od konvencionalnih firmi ili organizacija trećeg sektora koje se ne bave solidarnim radom. Radi se, dakle, o demokratskom ustroju i hijerarhijskoj strukturi donošenja odluka koja sve (važne) odluke vezane za financije i djelatnosti organizacije prepušta upravnom odboru i predsjedništvu organizacije. Ponekad se u odlučivanje uključuju vanjski dionici (članovi ili korisnici) ili pak vanjska savjetodavna tijela, međutim ne postoji zaista alternativna praksa donošenja odluka kao što su, primjerice, konsenzus ili participatorna demokracija. Razlog tome možemo tražiti u formalno-pravnom okviru koji propisuje upravljačku strukturu organizacije, iako, s druge strane, poštivanje formalno pravnog okvira ne isključuje ostale oblike donošenja odluka u praksi i uključivanje „čvršćih“ demokratskih praksi.

\subsubsection{Zagovaranje javnih politika}

Prilikom opisivanja djelovanja svojih organizacija ispitanici su često govorili o načinu na koji pokušavaju ostvariti utjecaj na lokalnu zajednicu, određenu legislativu vezanu za područje rada organizacije ili korisnike organizacije. Zagovaranje javnih politika vrši se direktno, kroz utjecaj i suradnju s lokalnim vladajućim strukturama ili $\mathrm{s}$ ministarstvom te indirektno, uglavnom kroz javna istupanja u medijima.

„Progovaramo u javnosti, mediji su nam u tome jako pomogli, dakle da kontinuirano govorimo, a promjene su nastale što smo zaista bili uporni da 
svake godine radimo konferencije i te zaključke šaljemo Ministarstvu, da ih pozivamo, da im stalno govorimo o korisnicima o kojima skrbimo. Radili smo stalno neformalne mreže, ukrupnjavali smo se, povezivali na lokalnoj, na regionalnoj, na nacionalnoj razini."

Slika 5.

Tema "zagovaranje javnih politika" i pripadajući kodovi

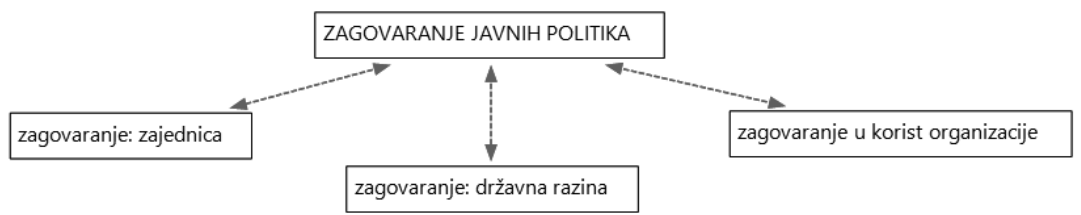

Tu temu odvajamo od teme društvenog utjecaja jer se odnosi na aktivnosti organizacija usmjerenih na konkretan legislativni okvir kojim se reguliraju prava i odgovornosti uključenih dionika. Iako su te aktivnosti često i neformalnog karaktera, postoje i suradnje s pravnim tijelima (lokalne) javne uprave te sudjelovanje u lokalnim samoupravnim jedinicama.

Ovisno o veličini i utjecaju organizacije, tu se radi o zagovaranju na nacionalnoj razini (često pri nadležnim ministarstvima, a vezano za određene zakone i propise), zagovaranju javnog interesa u lokalnoj zajednici ili interesa korisnika te zagovaranju interesa organizacije. Potonje se javlja sporadično, ukazivanjem na poteškoće u radu organizacija civilnog društva u Hrvatskoj. Ta se tema javlja rijetko u razgovorima s ispitanicima. Čak i kada su pitani da izraze stav o zakonodavnom okviru koji određuju područje njihovog djelovanja ili prijedloge poboljšanja, ispitanici su odgovarali šturo, bez prevelikog oslanjanja na konkretne formalne zakone ili propise. Razlog tome nalazi se u prethodnoj temi; naime većina organizacija djelatnosti organizira neformalno. Ništa što rade nije kršenje zakona, ali vlastite aktivnosti ne vezuju strogo uz propise ili nalaze načina kako im se prilagoditi da bi ostvarili ciljeve.

Možemo reći da većina organizacija ne radi sustavno na zagovaranju javnih politika ili javnog interesa, već konkretnim akcijama u lokalnoj zajednici nastoji rješavati probleme beskućništva, siromaštva, nejednakosti, diskriminacije i sl.

\subsubsection{Društveni doprinos}

Ako koncept solidarne ekonomije prema autorima uključuje i širu društvenu promjenu (kroz promjenu tržišnih odnosa i odnosa moći, ali i kroz sociokulturnu integraciju marginaliziranih skupina), važno je bilo razgovarati s ispitanicima o tome kako oni vide društveni doprinos kroz svoj rad u organizaciji. 
Slika 6.

Tema „društveni doprinos“ i pripadajući kodovi

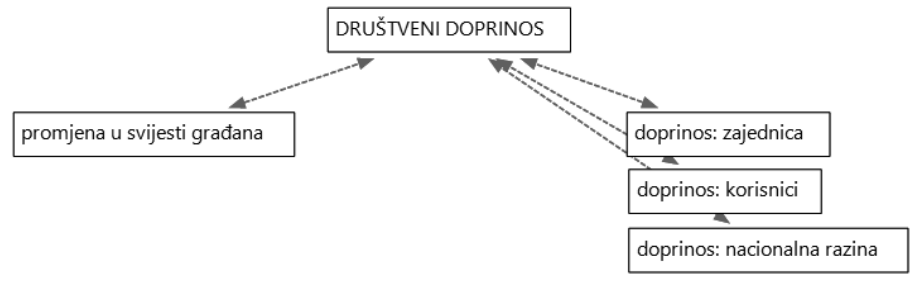

Društveni doprinos ispitanici opisuju kroz konkretna postignuća, koja se mogu grupirati u doprinos prema korisnicima, prema zajednici i doprinos na nacionalnom nivou. Pored navedenog, gotovo svi ispitanici ističu kako su doprinijeli „promjeni svijesti“ u zajednici prema marginaliziranim skupinama, prema volonterskom radu i sl.

„Senzibiliziranost u gradu Splitu na potrebe ljudi na margini... jako smo tu jednu koheziju građana na naše akcije, kad više tisuća građana svakodnevno donosi hranu, kad radimo akciju, mi više uopće medije ne informiramo, nama se sad događa da nas pitaju deset dana prije jel' sada akcija kreće, dakle to je ušlo kao nešto 'must be' $i$ to mislim da je velika promjena."

Pored promjene u svijesti građana, koju možemo odrediti kao subjektivnu promjenu u (lokalnom) društvu, značajan je i konkretan doprinos koji se objektivno pokazuje u legislativi, te se odnosi na senzibilizaciju ne samo lokalnog stanovništva već i formalno-pravnog okvira na nacionalnoj razini prema potrebitim skupinama građana.

„Ono što smo formalno na nekoj široj razini napravili, uspjeli smo promijenit neke zakone, $i$ to mislim da je jako vidljivo kroz rad s beskućnicima, nakon 11 godina upornog govorenja, zagovaranja, ta riječ 'beskućnik' ušla je u zakon o socijalnoj skrbi, uspjeli smo utjecat i na zakon o prebivalištu. "

Promjenom legislativnog okvira, posebice nekih propisa na lokalnoj razini doprinosi se i socijalnoj integraciji marginaliziranih skupina u društvo, što Singer (2007.) naglašava kao bitnu dimenziju solidarne ekonomije. U ovom slučaju konkretno se radi o mogućnosti osobne registracije pojedinaca (beskućnika) u sustav (vađenje osobne iskaznice s adresom utočišta), čime im se osigurava vidljivost u društvu i prekida začarani krug nemogućnosti izlaska iz beskućništva, zaposlenja i ostvarivanja socijalnih prava.

„Korisnici imaju prilike da osiguraju osobnu iskaznicu na našoj adresi ili na adresi centara za socijalnu skrb. To je velika revolucija jer zapravo su naši korisnici bili građani koji ne postoje, građani koji nisu mogli ostvariti niti jedno pravo iz socijalne skrbi, bez zdravstvene iskaznice, na tom još wvijek isto još radimo i danas su oni svi prijavljeni." 


\section{Zaključak istraživanja}

U kojoj mjeri možemo govoriti o razvijenosti solidarne ekonomije ostaje otvoreno pitanje, međutim prisutnost tog fenomena očigledna je, iako će se ključni akteri na tom području teško identificirati s konceptom. Unatoč tome što postoje elementi društvenog i ekonomskog djelovanja koji odgovaraju načelima solidarne ekonomije, većina se aktera ne identificira $s$ tim konceptom niti ima svijest o njegovom postojanju u takvom obliku. Solidarna ekonomija javlja se u specifičnom društveno-ekonomskom kontekstu, kojeg elemente možemo naći i u gradu Splitu. Ako se vratimo na ključne elemente solidarne ekonomije koje smo na početku ovog poglavlja ekstrahirali, tada možemo zaključiti da neki od tih ključnih elemenata odgovaraju elementima scene solidarnosti u Splitu. Radi se o naglašavanju principa koji umanjuju važnost maksimalizacije profita te alternativnim obrascima proizvodnje i potrošnje. Također je istaknut širi utjecaj na razvoj (lokalne) zajednice te osviještena potreba aktera za promjenom neodrživog ekonomskog sustava. Samoupravljanje i kolektivno vlasništvo, kao bitan element solidarne ekonomije, isključiv su oblik djelovanja ključnih aktera sudionika našeg istraživanja.

Rad bez novčane naknade i ne-novčana razmjena također su neizostavni elementi tog koncepta. Na taj način rad se vrednuje i poštuje, bio on plaćen ili ne, zato jer stvara vrijednost i doprinosi razvoju i pojedinca i zajednice. Važno je razumjeti kako solidarna ekonomija nije puki servis za siromašne, već nastoji nadići sve društvene nejednakosti te osnažiti i uključiti (ne samo ekonomski) marginalizirane skupine (RIPPES, 2015.:2). To je posebice istaknuto obilježje splitskih organizacija, koje nisu samo servis za siromašne, već pronalaze inovativne načine uključivanja raznih marginaliziranih skupina u društvo, od beskućnika do devijantnih mladih, fizički hendikepiranih osoba i sl., što je vidljivo iz rezultata istraživanja.

Akteri solidarne ekonomije u gradu Splitu kolektivno su organizirani oko zajedničkih društvenih ciljeva, kojima je dana prednost pred maksimalizacijom profita. Oni se svojim djelatnostima i organizacijskim oblicima uklapaju u treći sektor, pored privatnog i javnog sektora, nastojeći na inovativan način izbjeći negativne aspekte prvih dvaju sektora te riješiti postojeće društvene probleme. Istovremeno, neke od tih organizacija javno zagovaraju poboljšanje pravnog okvira vezano za svoje korisnike, ali ipak manje za sektor koji obuhvaća njihovu djelatnost ili pak sferu socijalne ekonomije (koju smo okarakterizirali kao krovni pojam solidarne ekonomije). Potonje predstavlja i jedno od ograničenja solidarne ekonomije u Splitu budući da se time umanjuje potencijal stvarne promjene (ekonomskog) sustava, što predstavlja jednu od glavnih odrednica koncepta. Sljedeće ograničenje tiče se ekonomske aktivnosti, koja je ograničena kod aktera iz našeg istraživanja, pretežno je uslužna te gotovo u potpunosti ovisi o donacijama, volonterskom radu i financiranju iz fondova (iako postoji trend razvoja i širenja ekonomskih aktivnosti). Daljnji razvoj solidarne ekonomije u Splitu ovisit će o kapacitetima jedne udruge, kao vodećeg aktera, da i dalje okuplja druge aktere i promovira koncept, što je rizična pozicija za strateški razvoj cjelokupnog koncepta. 


\section{Literatura}

1. Barić M. (Ur.) (2015). Hrvatski zavod za zapošljavanje - Godišnjak 2014. HZZ, Zagreb.

2. Bayertz K. (1999). Four Uses of 'Solidarity', in: Bayertz K. (Ed.). Solidarity. Dordrecht: Kluwer Academic Publishers, p. 3-28.

3. Dash A. (2014). Toward an Epistemological Foundation for Social and Solidarity Economy. Occasional Paper 3 - Potential and Limits of Social and Solidarity Economy. Geneva: UNRISD.

4. Fórum Brasileiro De Economia Solidária (FBES) (2006). (http://www.fbes.org. br).

5. Jost J. T. and Kay A. C. (2010). Social Justice: History, Theory and Research. Handbook of Social Psychology. 3:III:30, p. 1121-1165.

6. Kawano E. (2010). Crisis and opportunity: The emerging solidarity movement, in: Kawano E.; Masterson T. and Teller-Elsberg J. (Eds.). Solidarity Economy I. - Building Alternatives for People and Planet. Amherst, MA: Center for Popular Economics, pp. 11-23.

7. Kawano E. (2013). Social Solidarity Economy: Toward Convergence across Continental Divides. Pregledano 25.11.2015. (http://www.unrisd.org/unrisd/website/newsview.nsf/(httpNews)/F1E9214CF8EA21A8C1257B1E003B4F65?OpenD ocument).

8. Lalić, D.; Nazor, M.; Grubišić, I.; Mardešić V. (1997). Pojavnost i uvjetovanost zloporabe droge u Splitu. Split: Informacijski centar za mlade.

9. Lalić, D. i Nazor, M. (1999). Socijalna i zdravstvena ugroženost u gradu Splitu, (neobjavljeni tekst).

10. Lalić, D. (2002). Političari i problemi: vodeći političari Splita o problemima grada. Politička misao, 39 (3): 106-126.

11. Laville, J.-L., and M. Nyssens (2001). The Social Enterprise. Towards a Theoretical Socio-economic Approach, in: C. Borzaga and J. Defourny (Eds.). The Emergence of Social Enterprise. London and New York: Routledge, p. 312-332.

12. Lemaitre, B., Helmsing, A. (2011.) Solidarity Economy In Brazil: Movement, Discourse And Practice. Analysis through a Polanyian understanding of the economy, Working paper 524. (https://www.researchgate.net/profile/Ahj Helmsing/ publication/239806628 Solidarity economy in Brazil movement discourse and_practice._Analysis through_a_Polanyian_understanding_of the economy/ links/55195c710cf2d241f3563ae5.pdf).

13. Miller, E. (2010). Solidarity Economy: Key Concepts and Issues, in: Kawano E.; Masterson T. and Teller-Ellsberg J. (Eds.). Solidarity Economy I: Building Alternatives for People and Planet. Amherst, MA: Center for Popular Economics, p. 25-41. Pregledano 15.11.2015. (http://www.communityeconomies.org/site/assets/media/Ethan_Miller/Miller_Solidarity_Economy_Key_Issues_2010.pdf).

14. Moulaert F. and Ailenei O. (2005). Social Economy, Third Sector and Solidarity Relations: A Conceptual Synthesis from History to Present. Urban Studies, 42 (11): 2037- 2053.

15. Orlić, O. (2014). Grupe solidarne razmjene - početci ekonomije solidarnosti u Hrvatskoj. Etnološka tribina, 37 (44): 77-84. Zagreb: Institut za antropologiju. 
16. Polanyi, K. (1944). The Great Transformation. The political and economic origins of our time. Boston: Beacon Press.

17. Pusić E. (1974). Razvedenost i povezanost. Zagreb: Encyklopedia moderna.

18. Relja, R. i Bešker, M. (2011). Stručno obrazovanje u funkciji zapošljavanja na tržištu rada grada Splita. Andragoški glasnik: Glasilo Hrvatskog andragoškog društva, 15 (2): 152-152.

19. RIPESS (2015). Global Vision for a Social Solidarity Economy: Convergences and Differences in Concepts, Definitions and Frameworks. Pregledano 1.12.2015. (http://www.ripess.org/wp-content/uploads/2015/02/RIPESS Global-Vision EN.pdf).

20. Singer P. (2007). The solidarity economy in Brazil, in: Jeantet T. and Poulnot J.-P. (Eds.). The Social Economy. A global alternative. Paris: Éditions-Diffusion Charles Léopold Mayer, pp. 44-55.

21. Stanić, S. i Buzov, I. (2009). Recikliranje i zbrinjavanje otpada - stavovi i aktivnosti studenata. Titius, 2 (2): 275-296.

22. Stanić, S.; Buzov, I. i Galov, M. (2009). Prakse urbanog stanovništva u zbrinjavanju kućanskog otpada. Socijalna ekologija, 18 (2): 130-156.

23. Unković, L. i Majdak, M. (2010). Zloporaba opojnih droga među adolescentima na području grada Splita. Napredak, 151 (1): 45-68.

24. Utting P. (2014). Raising the Visibility of Social and Solidarity Economy in the United Nations System, in: Vielta M.; Lopes A. M.; Neamtan N.; Morais L. P.; Abreu A. T.; Marinho Alves da Silva R.; Pamplona L.; Utting P.; Noya A. (Eds.). The reader 2014: social and solidarity economy - towards inclusive and sustainable development. Torino: International Training Centre of the ILO, p. 145-163.

25. Utting P. (Ed.) (2015). Social and Solidarity Economy. Beyond the Fringe?. London: Zed Books Ltd. 
Jelena Puđak

Institute of Social Sciences Ivo Pilar, Zagreb, Croatia

e-mail: jelena.pudjak@pilar.hr

Filip Majetić

Institute of Social Sciences Ivo Pilar, Zagreb, Croatia

e-mail: filip.majetic@pilar.hr

Dražen šimleša

Institute of Social Sciences Ivo Pilar, Zagreb, Croatia

e-mail: drazen.simlesa@pilar.hr

\title{
Solidarity Economy Potential in the City of Split - A Qualitative Study
}

\begin{abstract}
The main aim of the paper was to explore whether the solidarity scene in Split had some of the basic characteristics of the solidarity economy concept. The research encompassed the key actors of the solidarity scene in Split, i.e. we used a purposive sample combined with the snowball method that contained 21 persons holding managerial positions in 9 organizations of various legal and organizational form (e.g. associations, cooperatives, political initiatives, companies). Semi-structural interviews were conducted, and the data was analyzed in the computer program for analyzing qualitative data (Atlas.ti), using the thematic analysis method. The analysis revealed six themes through which the interviewees were describing their activity in the field of solidarity and attitudes to their own social contribution and the solidarity economy concept. These themes were: the field of work, definitions of solidarity economy, work organization, decision making structure, public policies advocacy and social contribution. It has been discovered that some of the unavoidable elements of the Split's solidarity scene correspond to some of the basic characteristics of the solidarity economy concept and that the key actors in the field are having a hard time identifying themselves with the concept.
\end{abstract}

Key words: solidarity economy, scene of solidarity, Split. 